\title{
THE SEGMENTAL INFORMATION DISCLOSURES IN ACCORDANCE WITH THE REQUIREMENTS OF IFRS 8
}

\author{
Rezan Salahaddin Azzat \\ The College of Administration and Economics -Salahaddin University-Erbil
}

\begin{abstract}
This research purposes at identifying the level of segmental information disclosure in the annual financial reports of the banks operating in Iraq for the period 2016, through the use of indicators prepared in accordance with the requirements of IFRS 8 . The significance of the research stems from the reputation of objective information provided by the segmental financial reports that contribute to the addition of a new type of accounting information on the performance of the bank's segments to meet the needs of the financial reports users. However, in accordance with the research findings, this research presented a set of recommendations, the most important is the necessity of the banks operating in Iraq to comply with all the requirements of the segmental information disclosure that are in line with the requirements of IFRS 8 .
\end{abstract}

Keywords: information, banks

\section{Introduction}

Corporate (bank) extensive financial reporting alone is insufficient to assist users in accessing accurate and objective corporate performance evaluations because of the limited capacity of their numbers to capture disparities in the performance of the corporation's segments. Thus, the high levels of aggregation affect the value of information in overall financial reports. In this direction, some professional accounting boards and organizations have identified the negative effects of high levels of aggregation in financial reports, including the US and international accounting standards board (IASB). While, at the July 2010 meeting of the board of
Original Scientific Paper doi:10.5937/jouproman6-17819

directors on the draft IFRS presentation, the negative effects of aggregation levels identifies in the financial reports.

However, for some bank' differences in aggregation levels between financial statement items are difficult to understand and analyze by the users. Therefore, the overall financial information at the corporation level as a whole does not fully meet the needs of users, as this information makes it difficult for users to understand and analyze the corporation's activities and financial performance independently due to the expansion and diversification of multiple activities practiced by banks and geographic regions. Which requires the attention to the segmental information of corporations that have more activity, which requires these banks to provide information for each segment of business to be useful in evaluating the results of the corporation's business, and banks can provide detailed information including complete financial statements for each segment works.

Given the importance of the information provided by the segmental reports, the research deals with the exploration of the practices of banks operating in Iraq concerning the segmental information disclosure in published financial reports through the use of a model in assessing the level of segmental information disclosure in published financial reports. 
The importance of the research lies in the significance of the information provided by the segmental financial reports whether it is information about business segments or geographical segments, as it consists of information content that helps to evaluate the performance of banks in a way that affects the rationalization of the decisions of users of accounting information.

However, the research aimed to assess the reality of the segmental information disclosure in the banks operating in Iraq based on the accounting standards issued by the professional accounting committees and boards, especially the IFRS 8 .

\section{The Concept of Segmental Information Disclosure}

Accounting disclosure means the inclusion of financial reports on all information necessary and necessary to provide users of these reports a clear and correct image of the accounting unit. According to Abubakr et al., (2017: 353) as a result of the development and expansion of economic activity besides the emergence of large-scale projects on the geographical level and the various activities carried out by these projects. While, accounting disclosure in its traditional form is not meet the needs of users, as the financial reports prepared by the corporations contain a summary of achievements at the macro level. The managers of these corporations can manage the corporation efficiently and effectively, they need information about the corporation at the level of the segment does not need the need at this point, but the external users of the information corporation need information on segments that are one such corporation and to make decisions.

In this context, Garrison \& Norin, (2013: 602) argued that some managers can work efficiently. Thus, they need information about the results of the departments they manage instead of the need for a single income statement for the whole corporation. Provides a statement of the corporation's income as aggregate summary information for all operations of the corporation does not contain sufficient details allow the manager to discover opportunities and problems that may exist in the corporation (bank), for instance, a product may be more profitable while others are unprofitable. Some sales offices may be more efficient than others, or some factories do not use the energy or resources available to them efficiently.

Increasingly, more and more information sought as a result of the need for this type of information. Many financial analysts and investors have called for the disclosure of segmental information. In response to requests from financial analysts and investors, many professional organizations have issued accounting standards that require segmental information disclosure. However, the FASB issued standard No. 14 of 1976, corporate segment financial reporting, which was replaced by standard No. 131 of 1997, the disclosure of corporate segments and associated information.

Consequently, the International Accounting Standards Board (IASC) issued IASC14, which amended in 1997, and was replaced by IFRS 8 in November 2006. The segment information is disclosed by dividing the corporation into a number of the segments. As, (Mantiziou, 2014: 17) mentioned the operating segment also intended for the independent unit within the corporation that achieves a specific profit and has separate accounting records within the corporation, under which the performance and efficiency of the unit assessed. 
As can realize from the above definition, any part of the corporation to which the conditions set out in the definition can consider as an operating segment. Accordingly, Aljaarat, (2017: 435) believed that corporations could classify their activities by operating segments in several ways, including dividing the corporation according to the nature of the activities so-called activity segments or geographical segments or by combining the segments of activity and the geographical segments. The activity and the geographical segments can express as follows:

First, activity segment is a branch of the corporation that provides a specific product, service, or set of products or services. However, is subject to risk and has different returns than other segments.

Second, the geographical segment is a branch of the corporation were providing products and services in a particular economic environment, while it is subject to risk and has different returns from other branches of the Corporation operating in other economic environments.

From the above, it is possible to present many different views on the definition of the segmental information disclosure. While, (Epstein \& Mirza, 2002: 780) defined that it is the disclosure of information on operations in various industries, foreign sales, export sales and key customers of the corporation.

Nevertheless, there are those who believe that the segmental information disclosure is the division of the corporation into segments, whether business or geographical segments and the presentation of the financial statements fragmented with the corporation's total information (Roberts, 2002: 420). However, (Nikolai \& Bazley, 2009: 263) believe that segmental information disclosure means disclosing the material information of the main sectors that comprise the corporation to judge the corporation's position and market value and assess its ability to generate cash flows in the future. In the same regard, Nobes $\&$ Parker, (2010: 428) identify the segmental information disclosure as the division of the corporation's overall reporting information into detailed information for each section of the corporation to provide more detailed information on the performance of the corporation components. Thus, it believes that the concepts of segmental information disclosure as one of the forms of expansion of accounting disclosure does not replace the disclosure of the total information and is complementary to it, to help users of financial reports to make rational economic decisions.

The primary objective is to disclose segmental information in corporations in providing information on their core sectors related to the dissemination of information about the types of business activities and the economic conditions in which the corporation operates. And the opinion of the US accounting standard FASB No.131 disclosure about segment of an enterprise and related information and IFRS No.8 operation segments the objectives of the disclosure of segment information are to assist users of financial reports on: (FASB, standards No 131,1997: 5) and (IASB, standards No $8,2006: 4)$ :

a) Gain a better understanding of the corporation's diverse activities.

b) Better estimate the corporation's returns, risk and estimate future cash flows.

c) To arrive at a better opinion based on more information on the overall performance of the corporation with a variety of activities. 
On the other hand, the British Accounting Standard (SSAB No.25 Segmental Reporting) states that the purpose of disclosing segment information is to provide information that helps users of financial reports to (ASC-SSAB No. 25, 1990):

a) Appreciate the overall and suitable results of the corporation and its financial position to understand the performance of the corporation in the past and better or better estimate of future trends.

b) The users of financial reports are fully aware of the impact of changes in the core components of the corporation's activities on the corporation's overall activity.

The researcher believes that the objectives of the segmental information disclosures are similar to the objectives of the disclosure of aggregate information (financial report), it is an integral part of the financial reports published by corporations at the end of the financial period. Moreover, that its objectives derived from and complementary, despite differences in measurement procedures and how to view accounting information particularly those relating to the nature and form of disclosure.

The significance of disclosing the information produced by the segmental reports explained by the fact that they explain the figures are appearing in the overall financial reports. Therefore, according to Roberts, (2002: 375), the significance of disclosing segment information can explain the following points:

$$
\begin{aligned}
& \text { 1. Disclosure of } \\
& \text { information helps current and }
\end{aligned}
$$

prospective investors to make investment decisions about the allocation of their resources and investments. Especially, when there is a difference in the rates of profitability of the operating sectors and growth according to the detailed information published thereon, hence we find that the accounting information in the operational sectors has more value and more fit from the total information.

2. Segmental information facilitates more significant control over the decisions of the corporation's managers, reduces the diversity of information between managers and owners of the corporation and improves the efficiency of the corporation's investment activities.

3. The availability of segmental information in the case of opening new sectors, whether business segments or geographical segments of monitoring and tracking the results of work across different periods and identify the impact of new segments on the results of the work in this period (Ozu \& Cray, 2001: 5).

4. Segmental information disclosure helps to better assess the performance of corporations by making comparisons between the performance of a corporation operating in a particular sector with other corporations or banks operating in the same sector or comparison with other corporations with a single product operating in the same field. As one unit based on the performance of all sectors combined. (Benjamin et al., 2010: 32). 
5. The segmental information disclosure helps to analyze and evaluate future cash flows that are expected to occur in the future and to estimate their timing and risks associated with investments, so as a result in better investment decisions and better allocation of economic resources (Nobes \& Parker, 2010: 446).

6. Segmental information helps to improve the accuracy of profit forecasts by financial analysts to help them assess current trends and their forecasts of independent financial market trends. (Botosan \& Stanford, 2005: 755).

\section{Disclosure of Segment Information Under IFRS 8}

The disclosure of segmental information is an interest of the International Accounting Standards Board (IASC) as the primary entity responsible for the preparation and publication of international standards. It issued accounting standards on this subject. In August 1981, the committee issued IAS 14 as the first relevant accounting standard segmental report on financial information at the segmental level, which entered into force for countries that applied international accounting standards on January 1, 1983. While, the standard adopted the industry input as a basis for determining or diagnosing the segments, similar to US Accounting Standard 14. However, according to Deceuninck, (2009: 5), IAS 14 provided a description of the activities of each specific industry and the components of the region for each geographic region. So, Hammad, (2006: 765) mentioned the criterion for disclosing segmental information in accordance with the following provisions:
1. Sales or other operating income with the statement of amounts derived or derived from external customers and the amounts generated from sales to other segments of the same exporting corporation.

2. Operational results of the segment.

3. Assets of the segment used.

4. The basis of pricing between segments

Since the criticisms to this standard, including those related to disclosure requirements that were generalized and the flexible terms used in the formulation of the Standard, IAS 14, entitled segmental report, issued in 1997 to replace the original standard and become effective on 1 July 1998. (IASC) IAS. 14R, 1997: 23). However, the standard was amended having taken into account the criticisms to the original version, especially those concerning the adoption of the standard for entrance to yield and risk-based management or entrance level, which classifies the corporation divisions to essential segments and sub-segments of importance (Street \& Nichols, 2002: 94).

The amended standard also focused on the four previous items themselves within the disclosure of primary or critical segments. As well as the following additional items such as segment liabilities, land cost, corporations, equipment and intangible assets acquired during the period, depreciation, non-depreciation expenses and share of profit and loss of a corporation joint venture or other investment. That account for under the equity method if all the operations of the associate are within that segment only and the amount of the investment related. 
Regarding the disclosure of secondary segments, the amended standard eliminates the requirement in the original standard concerning the outcome of the segment and replaces it with the cost of land, corporations and intangible assets acquired during the period. Realizing the international accounting standards approach, which is one of the objectives of the IASB, design to establish a joint approach between the International Accounting Standards Board (IASB) and the US Financial Accounting Standards Board (FASB) in September 2002. The subject of segmental information disclosure selected as one of the topics examined between the two chambers to reduce the differences between IAS 14 and IAS 131. As a result of the comparison between the two standards and the review of academic and research results conducted on the US and international standards, US IAS 131 Financial Instruments: The IASB has changed its standard to conform to US Standard No. 131. In this regard, a research conducted by Mardini, (2012: 61) mentioned that in January 2006, the International Accounting Standards Board (IASB) issued a draft of Standard No. (8). After receiving 182 comments on draft IFRS 8 issued by it on 9 January 2006 and its review of academic studies conducted on American Standard No. 131, decided to adopt the US method of reporting on segmental information for some reasons, including:

First, the academic studies conducted on the American Accounting Standard 131 indicate: (a) the information provided by the US standard improves the consistency, reliability, and timeliness of sectoral information, (b) the information provided by the US Standard improved the ability of users of financial statements to predict future profits and stock prices. Second, the reliance on the internal reporting system in the preparation of segmental reports provides more consistent information with other parts of the financial reports.

Third, the Board believed that the application of the new accounting standard would reduce the cost of preparing the segmental information to be borne by the corporation, as such information was already available to the corporation for administrative decision-making and performance evaluation purposes. Based on the points mentioned above and the necessary amendments to the draft new standard, the IASB issued on 30 November 2006 IFRS 8, which complies with the requirements of US accounting standard 131, operating segments and supersedes IAS No. 14 amended and effective as for January 1, 2009 (Liu, 2014: 3). According to International Arab Society of Certified Accountants IASCA, international financial reporting standards, (2013: 292) corporations require to disclose information that enables users of accounting information from a calendar of business activities and financial impacts through segmental information disclosure as follows:

1. General information.

2. Information about the reported profit or loss to the segment including the specific revenue and expenses included in the reported profit and loss for the segment, the assets, and liabilities of the segment and the measurement basis.

3. The matches.

4. Corporation-wide information.

However, since the focus of the research relates to the segmental information disclosure, the researcher will discuss the detailed requirements of these types of disclosures in the next section. 


\section{Method}

Data collection sources, so, to reach the research purpose and results, this research relied on the preliminary and secondary data. First, the research preliminary data collected as based on the annual financial reports published at the end of 2016 for the number of banks registered in the Iraqi Stock Exchange While, secondary data: obtained through available books, periodicals, scientific journals, international information network (Internet), Arab and foreign university letters, international accounting rules and standards related to the research topic.

\section{Sampling}

The research population consists of banks operating in Iraq and listed in the Iraqi Stock Exchange. However, to reach the results accurately in light of the research hypothesis some banks selected, which published financial reports for the year 2016, thus, (20) banks as a sample intended for this research.

\section{The Research Limitation}

As mentioned above this research examines the level of information disclosure for some banks listed in the Iraqi Stock Exchange market for securities. Therefore, the spatial limits of the research determined the Iraqi market for securities, while the temporal limits are in 2016 as the period for which data collected.

\section{The Research Problem and Hypothesis}

The study problem can pose through the following primary question: Is segmental information disclosed in the published financial reports of banks operating in Iraq by the requirements of IFRS 8 ?

Banks operating in Iraq disclose segment information in published financial reports by the requirements of IFRS 8 .
Thus, to test this hypothesis, this research applied to a group of banks operating in Iraq registered in the Iraqi market for securities through the analysis of the annual financial reports prepared by them for the financial period ending 2016. So, this period covers the implementation of IFRS 8 or operating segments. Though, the research consists of (20) of the largest banks in Iraq regarding size compared to other banks because it expected to be large-sized banks operating in multiple segments, whether an activity or geographical segments.

These banks also provide multiple services to customers in addition to their wide geographical spread, which would require the preparation of segmental reports for them. To measure the level of segmental information disclosure in the annual financial reports of the banks, the research sample base on the following items:

\section{First, Preparation of the Segmental Information Disclosure Indicators}

To measure the level of segmental information disclosure in the sample of the research, the researcher uses indicators prepared based on the detailed requirements of IFRS 8 . The focus is on the requirements of this standard to measure the level of disclosure of segmental information to:

1. The Iraqi financial markets Act No, 74 of 2004 obliges all listed corporations (banks) on the Iraqi financial markets including banks to disclose financial statements according to international accounting standards. Moreover, banking law number 40 of 2004 provides for the application of accounting rules and regulations conforming to international accounting standards. 
2. Issuing special instructions to banks operating in Iraq the Iraqi Central Bank CBI requiring them to prepare financial reports in accordance with the requirements of international standards, as well as obliging them to contract with one of the international auditing banks known to conduct assessments of their financial positions and the quality of their assets.

Accordingly, concerning the requirements as discussed in the previous section, the proposed indicator should consist of four main parts and divide into 22 items (or paragraph) as shown in Appendix (1). The following is a brief explanation of these parts of the proposed indicator:

\section{Part One, General Information}

This section comprises two items, which intend to disclose the factors used in identifying or diagnosing the segments, also comprising the basis of the corporation and the manner in which the management has adopted based on differences in products, services, geographic regions and regulatory environments or a combination. Thus, these collected to form a more significant segment. Moreover, public information also includes the types of products and services that the segment derives.

Part Two, Information on Profit or Loss or Assets and Liabilities of the Segment

This section contains 13 items designed to collect information about the required disclosures about profit or loss containing the specific revenues and expenses involved in the reported profit or loss, assets and liabilities segments, and the measurement basis adopted.

Part Three, the Matches
This section comprises four items aimed at collecting information on the required disclosures about the reconciliation of total revenue segment, profit, and loss, assets and liabilities segments with the corresponding amounts at the corporation level as a whole.

\section{Part Four, Corporation Disclosures}

In the same regard, this section contains three items aimed at collecting information about the required disclosures about revenue from external customers for each product or service, the disclosure of geographical information including revenue from external customers and noncurrent assets. As well as disclosure of crucial bank clients, if revenues exceed transactions with a foreign client is only $10 \%$ or more of the corporation's revenue.

\section{Second, Analysis the Results of the Level of Segmental Information Disclosure of the Surveyed Banks}

To reach this research results, the indicators prepared for the financial reports prepared at the end of 2016. However, to reach the measurement of the level of segmental information disclosure of these banks, weight was assumed (0) for each item of disclosure that is not available, while (1) for each item of disclosure for which segmental information is available. Based on the above, the level of disclosure for the sample of the research can provide as follows:

\section{The Level of Segmental Information Disclosure}

To obtain the measurement of the level of segmental information disclosure for each bank for the year of study, the ratio was calculated by dividing the number of items in which sectoral information is available on the total (22) items which represent the overall items of disclosure as reveals in the Table below (1): 
Table 1: Segmental Information Disclosure ratio for banks research Sample for 2016

\begin{tabular}{|c|c|c|}
\hline Sequence & Bank Name & Disclosure Ratio \\
\hline 1 & Bank of Baghdad. & 59.1 \\
\hline 2 & National Bank of Iraq & 54.5 \\
\hline 3 & Iraqi Islamic Bank for Investment and Development & 40.9 \\
\hline 4 & Tigris and Euphrates Bank for Development and Investment & 31.8 \\
\hline 5 & Credit Bank of Iraq & 27.3 \\
\hline 6 & The Islamic National Bank & 22.7 \\
\hline 7 & Bank of Babylon & 22.7 \\
\hline 8 & Ashur Bank & 22.7 \\
\hline 9 & Economy Bank & 22.7 \\
\hline 10 & Kurdistan International Bank for Investment and Development & 18.2 \\
\hline 11 & United Investment Bank & 13.6 \\
\hline 12 & Iraqi Investment Bank & 13.6 \\
\hline 13 & Al-Mansour Investment Bank & 13.6 \\
\hline 14 & Mosul Bank for Development and Investment & 13.6 \\
\hline 15 & Iraqi Union Bank & 9.1 \\
\hline 16 & $\begin{array}{l}\text { International Development Bank for Islamic Finance and } \\
\text { Investment }\end{array}$ & 4.5 \\
\hline 17 & Cihan Bank for Islamic Finance and Investment & 4.5 \\
\hline 18 & Bank Across Iraq for Investment & 4.5 \\
\hline 19 & Region's Commercial Bank & 4.5 \\
\hline 20 & Sumer Commercial Bank & 4.5 \\
\hline \multicolumn{2}{|r|}{ Overall average ratio } & $\% 20.43$ \\
\hline
\end{tabular}


As summarized in a table (1) that the level of segmental information disclosure for banks ranges between $4.5 \%$ at the lowest level and $59.1 \%$ the maximum level, so, the accounting level for the disclosure in banks reached $20.23 \%$. While, the highest level of information disclosure establishes at the bank of
Baghdad, which reached the level $59.1 \%$ of total segmental information disclosure. However, as reveals in a table below (2) the distribution of the percentage of segmental information disclosure to banks according to different categories as follows:

Table 2: Percentage of disclosure of sectoral information for banks Sample study for 2016

\begin{tabular}{|c|c|c|}
\hline Disclosure Ratios & \multicolumn{2}{|c|}{ The year 2016 } \\
\hline $\mathbf{1 - 1 0}$ & 6 & The ratio \\
\hline $\mathbf{1 1 - 2 0}$ & 5 & 30 \\
\hline $\mathbf{2 1 - 3 0}$ & 5 & 25 \\
\hline $\mathbf{3 1 - 4 0}$ & 2 & 25 \\
\hline $\mathbf{4 1}$ and above & 2 & 10 \\
\hline Total & $\mathbf{2 0}$ & 10 \\
\hline
\end{tabular}

As indicated in the Table (2) there are six banks or $30 \%$ of the sample size of the research whose segmental information checked for less than $10 \%$ in the survey period 2016. While, two banks, or $10 \%$ of the sample, examined their segmental information by more than $41 \%$ in the same period indicated.

The researcher notes that 18 banks, or about $90 \%$ of the sample size, have disclosed their segmental information by less than $40 \%$. However, this percentage also ranges from $10 \%$ to $30 \%$. These results demonstrate significant differences in the percentage of segmental information disclosure between banks, besides low the overall disclosure levels for all banks.

\section{Distribution of Disclosure Ratios According to the Segmental Information Disclosure}

As showed in a table below (3), that analyzed the overall level of segmental information disclosure indicators to the component items to provide a more detailed image of the disclosure levels. To achieve the desired objective, while the percentage of segmental disclosure for each item calculate the number of banks that disclosed the item divided by the total number of sample banks (20). 
Table 3: The level of segmental information disclosure in accordance with the terms of the disclosure indicators

Indicator Items

\begin{tabular}{|c|c|c|}
\hline \multirow[b]{3}{*}{ First, General information: } & \multicolumn{2}{|l|}{2016} \\
\hline & \multirow[t]{2}{*}{$\begin{array}{l}\text { Number of banks that } \\
\text { have a disclosed item }\end{array}$} & \multirow[t]{2}{*}{$\begin{array}{l}\text { Disclosure } \\
\text { ratios }\end{array}$} \\
\hline & & \\
\hline $\begin{array}{l}\text { - Factors used in determining the segments covered in } \\
\text { the financial reports. }\end{array}$ & 4 & $20 \%$ \\
\hline $\begin{array}{l}\text { - The types of products and services from which each } \\
\text { segment derives its revenue from financial reports. }\end{array}$ & 3 & $15 \%$ \\
\hline $\begin{array}{l}\text { Second, Profit or loss information, assets and segment } \\
\text { liabilities: }\end{array}$ & & \\
\hline - Profit or loss. & 14 & $70 \%$ \\
\hline - $\quad$ Revenue from external clients. & 11 & $55 \%$ \\
\hline $\begin{array}{l}\text { Revenue from transactions with the operating } \\
\text { segments of the same corporation. }\end{array}$ & 0 & $00 \%$ \\
\hline - Consumption and firefighting. & 3 & $15 \%$ \\
\hline - Interest income. & 1 & $05 \%$ \\
\hline - Interest expense. & 1 & $05 \%$ \\
\hline $\begin{array}{l}\text { - Income and expense items of relative importance in } \\
\text { accordance with paragraph } 97 \text { of IAS } 1 \text { financial } \\
\text { statements }\end{array}$ & 0 & $00 \%$ \\
\hline $\begin{array}{l}\text { - The corporation's share of profit or loss of associates } \\
\text { and joint ventures. }\end{array}$ & 1 & $05 \%$ \\
\hline - Income tax expense & 0 & $00 \%$ \\
\hline $\begin{array}{l}\text { - Non-monetary items excluding (depreciation and } \\
\text { amortization) }\end{array}$ & 0 & $00 \%$ \\
\hline $\begin{array}{l}\text { - Amount of investment in associates and joint ventures } \\
\text { in the equity method. }\end{array}$ & 1 & $05 \%$ \\
\hline $\begin{array}{l}\text { Amount of additions to non-current assets excluding } \\
\text { securities, deferred tax assets, defined benefit assets. }\end{array}$ & 2 & $10 \%$ \\
\hline
\end{tabular}




\begin{tabular}{|c|c|c|}
\hline - $\quad$ The basis adopted measurement. & 0 & $00 \%$ \\
\hline \multicolumn{3}{|l|}{ Third, Matches: } \\
\hline $\begin{array}{l}\text { - Total segment revenue in the financial statements with } \\
\text { the bank's revenue. }\end{array}$ & 10 & $50 \%$ \\
\hline $\begin{array}{l}\text { - The aggregate profit and loss of the segments in the } \\
\text { financial statements with the bank's profits and losses. }\end{array}$ & 14 & $70 \%$ \\
\hline $\begin{array}{l}\text { - Total assets of the segments in the financial statements } \\
\text { with the bank's assets. }\end{array}$ & 4 & $20 \%$ \\
\hline $\begin{array}{l}\text { - The total of the segment's financial reporting } \\
\text { commitments with the bank's commitments. }\end{array}$ & 3 & $15 \%$ \\
\hline \multicolumn{3}{|l|}{ Fourth, Corporation Disclosures: } \\
\hline $\begin{array}{l}\text { - Revenue from external customers for each product or } \\
\text { service. }\end{array}$ & 17 & $85 \%$ \\
\hline $\begin{array}{l}\text { - Information on geographical areas (revenue from } \\
\text { external customers, non-current assets) }\end{array}$ & 6 & $30 \%$ \\
\hline $\begin{array}{l}\text { - Revenue from senior customers (if } 10 \% \text { of the bank's } \\
\text { revenues exceed) }\end{array}$ & 0 & $00 \%$ \\
\hline
\end{tabular}

Through showing the results as revealed in the table (3) the percentage of segmental information disclosure for each indicator varies independently during the research period. While, there are items that have not disclosed permanently, like revenues from transactions with the operating segments of the same corporation. However, income and expense items of relative importance by paragraph 97 of IAS 1 financial statements.

Consequently, income tax expense, non-monetary items except depreciation and amortization. So, the basis adopted measurement as well as revenue from senior customers (if $10 \%$ of the bank's revenues exceed) that items have not disclosed. As a result, reveals that none of the disclosure items disclose at $100 \%$.

Subsequently, the minimum level of disclosure that has observed for in the segmental information for the item reached $50 \%$ of the items namely with any items of disclosure indicator disclosed by $100 \%$. The lowest level of segmental information disclosure item was constituting a $05 \%$ for the items as; Interest income as well as interest expense. Also, the bank's share of profit or loss of associates and joint ventures. Besides the amount of investment in associates and joint ventures in the equity method.

When we look at the same table (3), we can realize that the highest level of segmental information disclosure of the item concerned was the item of revenue from external clients for each product or service. In the second part or item four (disclosure at the corporation level) by $85 \%$ for the period indicated. 
The table above displays that the rate of segmental information disclosure for 2016 for the sample banks is $20.23 \%$, ranging between $(4.5 \%)$ in the minimum and $(59.1 \%)$ in the maximum, which is relatively low, and the statistical results revealed that 18 banks, or nearly $90 \%$ of the sample size, reported their segmental information by less than $40 \%$. However, from these results, there are significant differences in the ratio of segmental information disclosure among banks and the low level of disclosure for all banks. So, based on the preceding, the primary hypothesis rejected regard, the banks operating in Iraq disclose the segment information in the financial statements by the requirements of IFRS 8 .

\section{Conclusions}

The results of the research indicated that most of the sample banks did not disclose the segmental information. While these results showed that the general disclosure of segmental information in 2016 was $20.23 \%$ Which ranges from $(4.5 \%)$ in the minimum and $(59.1 \%)$ in the maximum). However, the statistical results also showed that 18 banks, or about $90 \%$ of the sample size, had disclosed their segmental information by less than $40 \%$.

The results also indicate that there are items that have not disclosed. These items include income from transactions with the same operating segments, income and expense items of relative importance by paragraph 97 of IAS 1, (Excluding depreciation and amortization), approved measurement basis, revenue from senior customers (if $10 \%$ of the bank's revenues exceed).

The results of applying the provisions of the segmental information disclosure indicator showed that the minimum level of disclosure, that disclosed the segmental information for the item reached $50 \%$ for the items: interest income, interest expense, corporation's share of profit or loss of associates and joint ventures, the amount of investment in associates and equity-sharing projects. The highest level of segmental information disclosure for the item concerned was the item of revenue from external clients for each product or service. In the second part or paragraph four (disclosure at the corporation level) by $85 \%$ for the for the period indicated.

\section{Recommendations:}

Based on the above results, the researcher recommends the following:

Recommending the supervisory authorities of the banks, including the Iraqi central bank and the accounting disclosure department in the Iraqi stock exchange, to oblige banks in Iraq to prepare segmental financial reports by the requirements of IFRS 8 and to issue severe consequences against banks that did not require this.

The reports of external auditors should include in the review of the financial statements of banks as to their commitment to disclose segment information in the financial reports published in accordance with IFRS 8 , to ensure the reliability of their reports in the information provided by the financial reports.

The researcher also recommends that establish training courses for specialists in banks, especially those working in the field of accounting segment financial reporting mechanisms and the necessary accounting information that must disclose in accordance with the requirements of IFRS 8 to be able to present this vital information accurately. The board of accounting and auditing standards in Iraq should issue a special accounting rule relating to the preparation of segmental financial reports specifying the detailed requirements for the preparation of these reports in accordance with the requirements of IFRS 8. 


\section{REFERENCES:}

[1] Abubakr, Zito Awla., Khdeer, Jarjees Mustafa, and Azzat, Rezan Salahaddin, (2017). The Effect of Segment Information Disclosure in Interim Financial Reports on the Quality of Accounting Information An Empirical Study. Tikrit Journal for economic and Management Sciences, Tikrit University, Vol. (1), No. (37).

[2] Accounting Standards Committee, (ASC) SSAB No. 25, (1990) Segmental Reporting, July.

[3] Al-Ja'arat, Khalid Jamal. (2017). International Financial Reporting Standards - Part 1, Dar Al-Safa Publishing and Distribution, Amman.

[4] Benjamin, Samuel Jebaraj., Muthaiyah, Saravanan., Marathamuthu, Srikamaladevi and Murugaiah, Uthiyakumar, (2010) A Study of Segment Reporting Practices: A Malaysian Perspective, The Journal of Applied Business Research, The Clute Institute, Vol. (26), No. (3).

[5] Botosan, Christinc \& Stanford, Mary, (2005) Managers, Motives to Withhold Segment Disclosures and the Effect of SFAS No. 131 on Analysis Information Environment, The Accounting Review, American Accounting Association, Vol. (80), No. (3).

[6] Deceuninck, Annelien, (2009) Segment Reporting of Belgian Listed Companies, Master Thesis, Gent University, Belgium.

[7] Epstein, Barry J \& Mirza, Abbas Ali. (2002). Interpretation and Application of International Accounting Standards, John Wiley, and Sons, Inc, New York.

[8] Financial Accounting Standards Board (FASB), (1997) Statement of Financial Standards No 131, Disclosure About Statement of an Enterprise and Related Information, December.

[9] Garrison, R.H. and Norin Erik (2013). Administrative Accounting. Translated into Arabic by Dr. Mohammed Essam Zaid and Dr. Ahmed Hamed Hajaj, Dar Al-Marikh Publishing, Riyadh.

[10]Hammed, Tariq Abdel-Aal. (2006). Financial Reports, University Publishing House, Alexandria.

[11] International Accounting Standards Board (IASB), (2006), International Financial
Reporting Standard No.8 " Operating Segments," November, Para. 5.

[12] International Accounting Standards Committee (IASC) IAS. 14R, (1997) Segment Reporting, August.

[13]Liu, Ying, (2014) The Usefulness of Segmental Information Disclosures and Analyst Forecast Efficiency, Master thesis, Auckland University of Technology, New Zealand.

[14]Mantiziou, Stamatina, (2014) The Effectiveness of IFRS 8: Operating Segment, Master Thesis, University Pierre - Mendes, France.

[15] Mardini, Ghassan H., (2012), The Impact of IFRS 8 on Segmental Reporting by Jordanian Listed Companies: An Analysis of Disclosure Practices and Some Stakeholders' Perceptions, doctoral thesis, University of Dundee, United Kingdom.

[16] Nikolai, Loren A. \& Bazley, Johen D. (2009), Intermediate Accounting, Cengage Learning, $11^{\text {th }}$ Edition, Thomson southwestern, U.S.A.

[17] Nobes, Christopher \& Parker, Robert, (2010) Comparative International Accounting, 11th Edition, Pearson Prentice Hall, New York.

[18] Ozu, Chikako \& Cray, Sidney, (2001), The Development of Segmental Reporting in Japan: International Harmonization Through A process of National Consensus, Advances in International Accounting, Elsevier, Vol. 14.

[19] Roberts, Clare, (2002) Segment Reporting. In: Comparative International Accounting, 6th Edition, Prentice-Hall, New York.

[20] Street, Donna L \& Nichols, Nancy B, (2002), LOB and Geographic Segment Disclosure: An Analysis of IAS 14 Revised, Journal of International Accounting, Elsevier, Vol.11, No. 2.

[21] Annual Financial Reports of Banks Survey Sample, 2016.

[22] The International Arab Society of Certified Accountants IASCA, (2013), International Financial Reporting Standards, Talal AbuGhazaleh Organization, Amman. 
Appendix 1: Index of segment information disclosure in accordance with IFRS 8

\begin{tabular}{|c|c|c|}
\hline \multicolumn{2}{|r|}{ Indicator items } & 2016 \\
\hline \multicolumn{3}{|c|}{ First, General information: } \\
\hline 1 & Factors used in determining the segments covered in the financial reports. & \\
\hline 2 & $\begin{array}{l}\text { The types of products and services from which each segment derives its revenue from } \\
\text { financial reports. }\end{array}$ & \\
\hline \multicolumn{3}{|c|}{ Second, Profit or loss information, assets and segment liabilities: } \\
\hline 3 & Profit or loss. & \\
\hline 4 & Revenue from external clients. & \\
\hline 5 & Revenue from transactions with the operating segments of the same corporation. & \\
\hline 6 & Consumption and firefighting. & \\
\hline 7 & Interest income. & \\
\hline 8 & Interest expense. & \\
\hline 9 & $\begin{array}{l}\text { Income and expense items of relative importance in accordance with paragraph } 97 \text { of } \\
\text { IAS } 1 \text { financial statements }\end{array}$ & \\
\hline 10 & The corporation's share of profit or loss of associates and joint ventures. & \\
\hline 11 & Income tax expense & \\
\hline 12 & Non-monetary items excluding (depreciation and amortization) & \\
\hline 13 & Amount of investment in associates and joint ventures in the equity method. & \\
\hline 14 & $\begin{array}{l}\text { Amount of additions to non-current assets excluding securities, deferred tax assets, } \\
\text { defined benefit assets. }\end{array}$ & \\
\hline 15 & The basis adopted measurement. & \\
\hline \multicolumn{3}{|c|}{ Third, Matches: } \\
\hline 16 & Total segment revenue in the financial statements with the bank's revenue. & \\
\hline 17 & $\begin{array}{l}\text { The aggregate profit and loss of the segments in the financial statements with the } \\
\text { bank's profits and losses. }\end{array}$ & \\
\hline 18 & Total assets of the segments in the financial statements with the bank's assets. & \\
\hline 19 & $\begin{array}{l}\text { The total of the segment's financial reporting commitments with the bank's } \\
\text { commitments. }\end{array}$ & \\
\hline \multicolumn{2}{|r|}{ Fourthly, Corporation Disclosures: } & \\
\hline 20 & Revenue from external customers for each product or service. & \\
\hline 21 & $\begin{array}{l}\text { Information on geographical areas (revenue from external customers, non-current } \\
\text { assets) }\end{array}$ & \\
\hline 22 & Revenue from senior customers (if $10 \%$ of the bank's revenues exceed) & \\
\hline
\end{tabular}

